\title{
REVIEW
}

\section{Early referral recommendation for newly diagnosed rheumatoid arthritis: evidence based development of a clinical guide}

\author{
P Emery, F C Breedveld, M Dougados, J R Kalden, M H Schiff, J S Smolen
}

Ann Rheum Dis 2002;61:290-297

See end of article for authors' affiliations

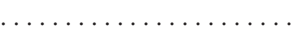

Correspondence to: Professor P Emery, Department of Rheumatology and Rehabilitation, University of Leeds School of Medicine, 36 Clarendon Road, Leeds LS2 9NZ, UK;

P.Emery@leeds.ac.uk

Accepted 29 August 2001

\begin{abstract}
Background: Effective treatment of active rheumatoid arthritis (RA) requires early diagnosis and early disease modifying antirheumatic drug (DMARD) treatment to have an impact on long term morbidity and mortality. Clinical criteria would facilitate early referral of the patient with suspected RA to a rheumatologist for definitive diagnosis and initiation of DMARD treatment at that point in the disease most likely to have an impact on the long term outcome.

Objective: To develop a referral recommendation that may serve as a clinical guide for primary care doctors, enabling them to identify patients with suspected RA during the early inflammatory stages.

Methods: Key points of the referral criteria were formed based on a thorough literature review targeting early RA, early arthritis clinics, DMARD treatment for early RA, prognostic factors of disease progression, early RA clinical trials, and quality of life. Evidence was graded using the methods defined by Shekelle et al. A draft version of the criterion was circulated among the authors for critical evaluation. A consensus integrated these comments.

Results: Clinical evidence strongly supports the observations that structural damage occurs early in active RA and that early DMARD treatment improves the long term outcome of the disease. The observations indicate that rapid referral to a rheumatologist is advised when RA is suspected. This may be supported by the presence of any of the following: $\geqslant 3$ swollen joints, metatarsophalangeal/ metacarpophalangeal involvement, and morning stiffness of $\geqslant 30$ minutes.

Conclusion: The proposed early referral recommendation is a viable tool for primary care doctors to identify potential patients with active RA early in the disease. Early referral to a rheumatologist for definitive diagnosis and early DMARD treatment should improve the long term outcome of RA.
\end{abstract}

A ctive rheumatoid arthritis (RA) is characterised by inflammation of the synovial tissue, which, if untreated, leads to permanent structural damage and eventual long term disability. Demographically, RA is the most common form of inflammatory arthritis and affects approximately $0.5-$ $1.0 \%$ of the global population, with an economic impact comparable with that of coronary artery disease. ${ }^{1}$ Given that $~ 90 \%$ of patients with RA have some form of disability within two decades of onset, ${ }^{2}$ early diagnosis and treatment of RA is of paramount importance. However, there are obstacles to early diagnosis and treatment, including the initial delay on the part of the patient to seek medical care, followed by a delay in primary care, where the early symptoms of RA are sometimes non-specific and inconclusive.

To deal with these obstacles, a referral recommendation has been developed that may serve as a clinical guide for primary care doctors, enabling them to identify patients with suspected RA during the early inflammatory stages. Early referral, followed by specific diagnosis of active RA and initiation of disease modifying antirheumatic drugs (DMARDs) during the early inflammatory stages of RA, will improve patient outcome and long term quality of life.

\section{PURPOSE OF THE REFERRAL RECOMMENDATION}

Clinical evidence, summarised in the following discussion, provides a clear indication of the benefits of early diagnosis and early DMARD treatment for the treatment of active RA. The purpose of the referral recommendation is to provide a tool based on clinical evidence that summarises the essential and basic diagnostic criteria, allowing early identification of the patient with suspected RA for referral to a rheumatologist.
A relatively brief opportunity may exist for initiating the DMARD treatment that can substantially improve the long term outcome of the disease, as well as the overall quality of life for patients with active RA.

Criswell et al show evidence of systematic differences between rheumatologists and non-rheumatologists in initiating the use of DMARDs for the treatment of RA. ${ }^{3}$ Nonrheumatologists generally delay treatment, which can result in substantial differences in the long term outcome of the disease. Other investigation $s^{4-6}$ have shown that patients with RA managed by rheumatologists maintained greater functional status over the duration of the disease and had better health outcomes. In addition, newer treatments require specialised administration and monitoring for maximal efficacy and safety.

\section{METHODS: CONSENSUS DEVELOPMENT}

The initial stage in the development of the early referral recommendation involved a literature search of the Medline and Current Contents databases. The key terms of the search were the phrase "early rheumatoid arthritis" AND, separately, the terms "disease progression", "clinical trial", "early arthritis clinics", "mortality", "quality of life", and "early treatment". Published clinical evidence was classified and graded

Abbreviations: $C R P, C$ reactive protein; DMARDs, disease modifying antirheumatic drugs; EACs, early arthritis clinics; ESR, erythrocyte sedimentation rate; HAQ, Health Assessment Questionnaire; MRI, magnetic resonance imaging; NSAIDs, non-steroidal anti-inflammatory drugs; RA, rheumatoid arthritis; RCTs, randomised controlled trials; RF, rheumatoid factor; US, ultrasound 


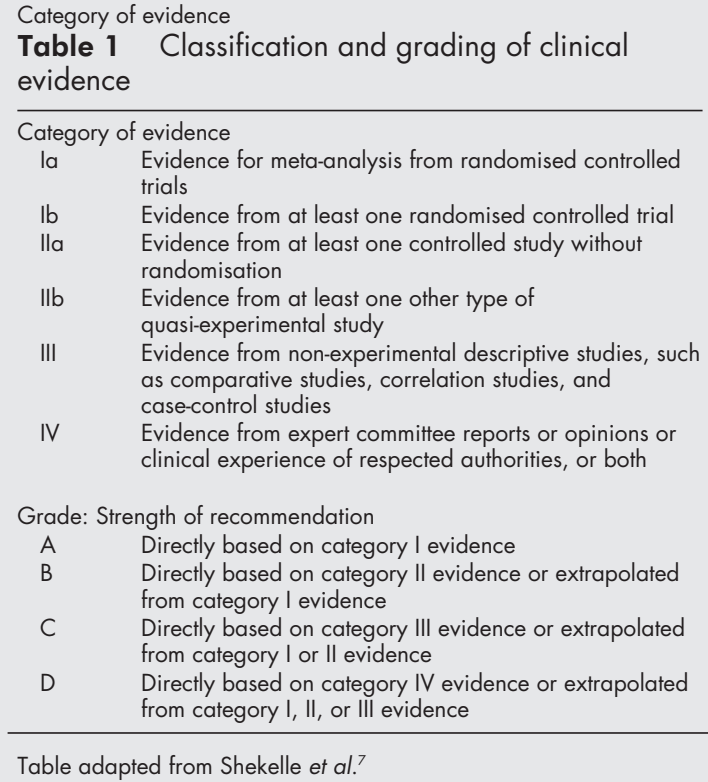

Table adapted from Shekelle et al.?

according to the methodology defined by Shekelle $e t \mathrm{al}^{7}$ and is summarised in table 1 .

Valid classification schemes categorise clinical evidence based on the potential for bias influencing the results. Thus the least biased, and therefore the highest category evidence (Ia, table 1) is represented by meta-analyses of randomised controlled trials (RCTs). Categories Ia and Ib (evidence from at least one RCT) provide support for a grade A recommendation. Conversely, the evidence category with the greatest potential for bias (category IV) is evidence from expert committees or the opinion of respected authorities ${ }^{7}$ and supports grade D recommendations. The evidence categories are open to interpretation, as questions about efficacy of intervention are most strongly addressed by RCTs, and clinical questions about risk are more appropriately assessed by prospective cohort investigations. ${ }^{7}$ Throughout this paper, evidence categories are indicated where appropriate by a Roman numeral and evidence grade by a letter, as defined in table 1 .

A draft version of the clinical recommendation was prepared synthesising the recommendation and supporting clinical evidence and was then circulated among the authors for further review and critical evaluation. A final draft of the clinical guide and referral recommendation was then generated, merging the comments and critique of the six participants; this resulted in a consensus statement for early referral recommendation.

\section{CLINICAL PROGRESSION OF RA: JOINT DAMAGE OCCURS EARLY}

Radiographically measured progression of RA remains the best method of assessing structural damage associated with the disease. An inherent problem in comparing clinical studies of radiographic progression is variability of the study designs. Three designs predominate: cross sectional studies, prospective studies of patients with disease of varying duration, and prospective follow up studies of a cohort of patients with early RA. ${ }^{8}$ Of the three designs, the prospective follow up studies of patient cohorts with early disease is the best design for assessing the risks of disease progression.

Summarising prospective studies of radiographic progression of patients with early RA, van der Heijde concludes that $\sim 75 \%$ of patients with early RA have joint erosions and develop the initial erosions within the first two years of symptom onset.' These early prospective investigations present strong evidence that joint damage occurs early in the course of RA (III).
A recent comprehensive evaluation of published reports which linked structural damage to disability ${ }^{10}$ concluded that joint damage progresses at a consistent rate over the course of the disease and that it accounts for $\sim 25 \%$ of the disability. The statistical association between radiographic damage and disability is strongest with disease duration of $>8$ years; however, prevention of structural damage early in the disease is likely to preserve patient function (III). ${ }^{11}$

Bone density is also seen to decrease during the early stages of RA. Measures of the axial bone mineral density ${ }^{12}$ in patients with RA with a mean disease duration of 10.4 months showed a significant reduction of axial and appendicular bone mineral density by one year. Mineral loss was closely correlated with raised $\mathrm{C}$ reactive protein (CRP) levels and functional impairment. Reduced peripheral bone mineral density was also seen with persistent disease. ${ }^{13}$ Patients with early RA with a median disease duration of nine months $(n=42)$ as a group lost a significant amount of hand bone mineral density over the 12 month period of the study compared with the control population. ${ }^{14}$ There was a concomitant worsening of the radiographic Larsen score, indicating progression of structural damage. Both studies were prospective investigations and constitute category III evidence.

Joint erosions that are evident radiographically represent permanent structural damage and have prompted the investigation of alternative imaging techniques to identify synovial changes before permanent deterioration has occurred. Both ultrasound (US) and magnetic resonance imaging (MRI) techniques have been applied to the evaluation of synovitis in patients with early RA. A controlled clinical investigation (IIa) of the interrelationship between synovitis and bone in early RA concluded that metacarpophalangeal joint bone oedema is present in the majority of patients with RA at presentation and that joint structural changes are secondary to synovitis. ${ }^{15}$

A prospective study employing blinded observers (IIb) evaluated the effectiveness of three phase bone scintigraphy, US, MRI, and contrast enhanced MRI to determine the optimal imaging method for identification of both early erosions and acute phase inflammation compared with conventional radiography. ${ }^{16}$ The early RA cohort had a mean disease duration of 19 months, and the results indicated that scintigraphy, US, and MRI were significantly more sensitive than conventional radiography at detecting early inflammatory soft tissue and destructive joint processes before radiographic damage becomes evident.

In support of the evidence for early synovitis preceding structural damage in RA, Kraan et al examined histological synovial biopsy specimens of the unaffected joints of patients with established RA for signs of inflammation. ${ }^{17}$ The synovial tissue of asymptomatic joints was characterised by infiltrating macrophages and macrophage derived cytokine expression indicative of active inflammation.

The combined clinical evidence indicates that the physiological changes induced by RA within the synovial environment are evident during the early asymptomatic phase of the disease and, when left untreated, chronic inflammation leads to structural damage in active RA. The bulk of the clinical evidence for early structural damage is derived from prospective studies and composed of category III evidence; therefore, the observation that damage occurs early is assigned evidence grade $\mathrm{C}$.

Tables 2 and 3 summarise selected prospective investigations dealing with the prognostic factors for radiographic progression and disability in early RA; table 4 isolates predictive factors evaluated in early arthritis clinics (EACs). Despite the heterogeneous results from these studies, common elements in the baseline risk factors exist for both radiographic progression and disability, including involvement of large joints, disease duration of $\geqslant 3$ months, involvement of hand joints, $\geqslant 2$ swollen joints, high disease activity at baseline, rheumatoid factor (RF) positivity, and raised CRP levels. ${ }^{18}$ 
Table 2 Risk factors indicative of radiographic damage in early RA

\begin{tabular}{|c|c|c|c|}
\hline Author (reference) & Study design & Risk factors at baseline & $\begin{array}{l}\text { Evidence } \\
\text { category }\end{array}$ \\
\hline Brennan et $a^{50}$ & $\begin{array}{l}\text { Prospective study of } 157 \text { patients with RA for } \\
1 \text { year }\end{array}$ & $\begin{array}{l}R F \geqslant 1 / 80, \text { involvement of } \geqslant 2 \text { large joints } \\
\text { and }>3 \text { months' disease duration }\end{array}$ & III \\
\hline Combe et $\left.a\right|^{51}$ & $\begin{array}{l}\text { Prospective study of } 191 \text { patients with RA for } 3 \\
\text { years }\end{array}$ & $\begin{array}{l}\text { RF positive, ESR, DRB 1 *04 gene, and } \\
\text { erosion score }\end{array}$ & III \\
\hline Feigenbaum et $a^{52}$ & Prospective study of 50 patients for $\geqslant 3$ years & $\begin{array}{l}\text { Involvement of } \geqslant 2 \text { swollen joints, white } \\
\text { female, Raynaud's symptoms, presence of } \\
\text { malaise or weakness }\end{array}$ & III \\
\hline Gough et a ${ }^{53}$ & $\begin{array}{l}\text { Prospective study of } 120 \text { patients with RA for } \\
1 \text { year }\end{array}$ & $\begin{array}{l}\text { RF positive and HLA-Dw4 or HLA-Dw14 } \\
\text { positive }\end{array}$ & III \\
\hline Möttönen et $a^{54}$ & $\begin{array}{l}\text { Prospective study of } 142 \text { patients with RA for } \\
6 \text { years }\end{array}$ & $\begin{array}{l}\text { High disease activity at baseline, RF positive } \\
\text { especially at } 1 \text { year }\end{array}$ & III \\
\hline van der Heide et a ${ }^{55}$ & $\begin{array}{l}\text { Prospective study of } 128 \text { patients with RA for } \\
1 \text { year }\end{array}$ & $\begin{array}{l}\text { RF positive, with radiographic damage } \\
\text { evident at } 1 \text { year }\end{array}$ & III \\
\hline van der Heijde et $a^{56}$ & $\begin{array}{l}\text { Prospective study of } 147 \text { patients with RA for } \\
\geqslant 2 \text { years }\end{array}$ & $\begin{array}{l}\text { High disease activity at presentation or CRP } \\
\text { levels, ESR or DAS, DR4+ or DR2-, RF } \\
\text { positive }\end{array}$ & III \\
\hline van der Horst-Bruinsma et $a^{\beta 5}$ & $\begin{array}{l}\text { Prospective study of } 139 \text { patients with RA for } \\
1 \text { year }\end{array}$ & RF positive and arthritis of hands and feet & III \\
\hline van Leeuwen et a ${ }^{57}$ & $\begin{array}{l}\text { Prospective study of } 149 \text { patients with RA for } \\
3 \text { years }\end{array}$ & Raised CRP and ESR and swollen joints & III \\
\hline van Zeben et a $\left.\right|^{58}$ & $\begin{array}{l}\text { Prospective study of } 132 \text { patients with RA for } \\
6 \text { years }\end{array}$ & $\begin{array}{l}\text { RF positive, number of swollen joints, and } \\
\text { erosion score }\end{array}$ & III \\
\hline
\end{tabular}

Table 3 Risk factors indicative of disability in early RA

\begin{tabular}{|c|c|c|c|}
\hline Author (reference) & Study design & Risk factors at baseline & $\begin{array}{l}\text { Evidence } \\
\text { category }\end{array}$ \\
\hline Eberhardt and Fex ${ }^{59}$ & $\begin{array}{l}\text { Prospective study of } 67 \text { patients with RA; } \\
\text { functional assessment - HAQ; } 1 \text { year study }\end{array}$ & Raised HAQ score at baseline, female, low education & III \\
\hline Harrison et a ${ }^{100}$ & $\begin{array}{l}\text { Prospective study of } 200 \text { patients with RA and } \\
181 \text { with inflammatory polyarthritis; functional } \\
\text { assessment - HAQ; } 1 \text { year study }\end{array}$ & Raised HAQ score at baseline, large joint involvement & III \\
\hline Möttönen et a ${ }^{54}$ & $\begin{array}{l}\text { Prospective study of } 142 \text { patients with RA; } \\
\text { functional assessment - HAQ; } 6 \text { year study }\end{array}$ & RF positive at 1 year, age $>60, \geqslant 4$ swollen joints & III \\
\hline van Leeuwen et $a^{\beta 1}$ & $\begin{array}{l}\text { Prospective study of } 149 \text { patients; functional } \\
\text { assessment-HAQ; } 3 \text { year study }\end{array}$ & Increased tender joint & III \\
\hline van Zeben et $a^{58}$ & $\begin{array}{l}\text { Prospective study of } 132 \text { patients with RA; } \\
\text { functional assessment - HAQ; } 6 \text { year study }\end{array}$ & RF positive, number of swollen joints, and erosion score & III \\
\hline Young et $a^{162}$ & $\begin{array}{l}\text { Prospective study of } 151 \text { patients with RA; } \\
\text { functional assessment - HAQ; } 3 \text { year study }\end{array}$ & RF positive & III \\
\hline
\end{tabular}

Prognostic factors for radiographic progression and disability constitute category III evidence.

\section{EARLY DMARD TREATMENT IMPROVES RA OUTCOME}

Table 5 shows the results of placebo controlled trials of early DMARD treatment for patients with early RA and disease duration $<2$ years. Treatment with sulfasalazine, oral gold, and hydroxychloroquine significantly reduced the clinical signs and symptoms of early RA, and hydroxychloroquine improved patient function as assessed by the Health Assessment Questionnaire (HAQ) after 11 months of treatment.

Analysis of delayed treatment trials (extensions of placebo controlled investigations in which the placebo group is switched to active treatment at the end point of the initial study) shows the efficacy of early DMARD treatment for early RA (table 6). In each trial the group treated at presentation with DMARDs showed significantly more improvement in efficacy parameters than the groups whose treatment was delayed. Early intervention improved patient function (reduced HAQ score in three of the four presented trials) and reduced or slowed radiographic disease progression, as well as decreasing swollen joint counts in $\sim 50 \%$ of the trials.

Recent evaluation of primary trial data from 14 RCTs of DMARD treatments in RA indicates that patients with a longer disease duration did not have such a good response as patients treated at earlier stages of the disease. ${ }^{19}$ The study also noted that prior DMARD use, RA functional classification, and disease activity also had an impact on the potential outcome of treatment (Ia).

A recently published study of an inception cohort of 622 patients with newly diagnosed RA followed up for up to 10 years, evaluated patient mortality, functional ability, and prognostic factors for mortality. ${ }^{20}$ The cohort of patients with early RA treated aggressively with DMARDs showed no excess mortality within the first 10 years when compared with the normal population, and functional ability remained constant after an initial improvement from baseline. Age at onset and male sex were the only significant prognostic factors for mortality. The results of this investigation highlight the efficacy of an early, aggressive therapeutic strategy, indicating that treatment with conventional DMARDs improves the disease course and gives long term patient benefit.

To date there have been no long term investigations of the newer biological treatments on patient mortality and functional ability; this will be critical in determining the role of these treatments in the aggressive treatment of early RA.

Randomisation and placebo controls in the summarised trials of early treatment (presented above) represent category Ia and Ib evidence and constitute grade A support for early intervention with DMARDs in early RA. 
Table 4 Risk factors for persistent RA, evidence from EACs

\begin{tabular}{|c|c|c|c|}
\hline Author (reference) & Study design & Risk factors at baseline & $\begin{array}{l}\text { Evidence } \\
\text { category }\end{array}$ \\
\hline Green et $a^{\beta 3}$ & $\begin{array}{l}\text { Prospective study of } 63 \text { patients with early RA; } \\
6 \text { months }\end{array}$ & Disease duration of $>12$ weeks & III \\
\hline Gough et $a^{53}$ & $\begin{array}{l}\text { Prospective study of } 120 \text { patients with early } \\
\text { RA; } 1 \text { year study }\end{array}$ & $\begin{array}{l}\text { RF positive, Dw4/Dw14 genotype high risk group for erosive } \\
\text { disease }\end{array}$ & III \\
\hline Harrison et $a^{1 / 3}$ & $\begin{array}{l}\text { Prospective study of } 258 \text { patients with early } \\
\text { RA; } 1-2 \text { year study }\end{array}$ & Female and swollen/tender joints & III \\
\hline Masi ${ }^{64}$ & $\begin{array}{l}\text { Prospective study of } 50 \text { patients with early RA; } \\
\text { mean study interval } 5.7 \text { years }\end{array}$ & RF positive, female, and swollen/tender joints & III \\
\hline Prevoo et a ${ }^{65}$ & $\begin{array}{l}\text { Prospective study of } 227 \text { patients with early } \\
\text { RA; median follow up } 3.9 \text { years }\end{array}$ & Swollen/tender joints and ESR as component of DAS score & III \\
\hline Tunn and Bacon ${ }^{66}$ & $\begin{array}{l}\text { Prospective study of } 65 \text { patients with early RA; } \\
1 \text { year study }\end{array}$ & RF positive, ESR, $30 \mathrm{~mm} / 1 \mathrm{st} h$ & III \\
\hline Wolfe $e^{67}$ & $\begin{array}{l}\text { Prospective study of } 503 \text { patients with early RA } \\
\text { and } 638 \text { with undifferentiated polyarthritis; } \\
\text { mean study interval } 6.9 \text { years }\end{array}$ & RF positive & III \\
\hline
\end{tabular}

Table 5 Placebo controlled trials of DMARD treatment for early RA

\begin{tabular}{|c|c|c|c|c|c|}
\hline $\begin{array}{l}\text { Author } \\
\text { (reference) }\end{array}$ & Study design & $\begin{array}{l}\text { Mean } \\
\text { disease } \\
\text { duration } \\
\text { (months) }\end{array}$ & Treatment & Outcome & $\begin{array}{l}\text { Evidence } \\
\text { category }\end{array}$ \\
\hline $\begin{array}{l}\text { Australian } \\
\text { Multicentre } \\
\text { Clinical Trial } \\
\text { Group }^{68}\end{array}$ & $\begin{array}{l}\text { Randomised, placebo controlled trial; } 105 \\
\text { non-erosive, DMARD-naive patients; } 6 \\
\text { month study }\end{array}$ & $<12$ & Sulfasalazine & $\begin{array}{l}\text { Significantly reduced swollen and tender } \\
\text { joints, ESR/CRP, RF, RI, and EMS }\end{array}$ & $\mathrm{lb}$ \\
\hline Borg et $a^{109}$ & $\begin{array}{l}\text { Double blind, randomised, placebo } \\
\text { controlled trial; } 138 \text { DMARD naive } \\
\text { patients; } 12 \text { month study }\end{array}$ & 11 & Oral gold & $\begin{array}{l}\text { Significantly reduced swollen joint counts, } \\
x \text { ray progression, and } \mathrm{HAQ} \text { functional } \\
\text { score }\end{array}$ & $\mathrm{lb}$ \\
\hline Davis et a PO $^{0}$ & $\begin{array}{l}\text { Double blind, randomised, placebo } \\
\text { controlled trial; } 104 \text { mild RA*, DMARD } \\
\text { naive patients; } 12 \text { month study }\end{array}$ & 14 & Hydroxychloroquine & $\begin{array}{l}\text { Significantly reduced RI synovial score, } \\
\text { ESR, EMS, and improved GS }\end{array}$ & $\mathrm{lb}$ \\
\hline Hannonen $^{71}$ & $\begin{array}{l}\text { Double blind, randomised, placebo } \\
\text { controlled trial; } 80 \text { DMARD naive patients; } \\
12 \text { month study }\end{array}$ & 5 & Sulfasalazine & $\begin{array}{l}\text { Significantly reduced swollen joint counts, } \\
\text { RI, PGA, pain, and improved GS }\end{array}$ & $\mathrm{lb}$ \\
\hline $\mathrm{HERA}^{72}$ & $\begin{array}{l}\text { Double blind, randomised, placebo } \\
\text { controlled trial; } 120 \text { DMARD naive } \\
\text { patients; } 8 \text { month study }\end{array}$ & 9 & Hydroxychloroquine & $\begin{array}{l}\text { Reduced swollen and tender joint counts, } \\
H A Q, E M S \text {, pain, and improved GS }\end{array}$ & $\mathrm{lb}$ \\
\hline \multicolumn{6}{|c|}{$\begin{array}{l}\text { DMARD, disease modifying antirheumatic drug; EMS, early morning stiffness; GS, grip strength; HAQ, Health Assessment Questionnaire; PGA, patient } \\
\text { global assessment of disease activity; RF, rheumatoid factor; RI, Ritchie Index. } \\
\text { *Mild RA defined as disease affecting hands and feet only, CRP }<20 \mathrm{mg} / \mathrm{l}, \mathrm{ESR}<30 \mathrm{~mm} / 1 \mathrm{st} \text { h. All patients satisfied either the } 1987 \text { revised ACR } \\
\text { diagnostic criteria, or the pre-1987 ARA diagnostic criteria. } \\
\text { Adapted from Quinn, Conaghan, and Emery. The therapeutic approach of early intervention for rheumatoid arthritis (submitted). }\end{array}$} \\
\hline
\end{tabular}

\section{EARLY DMARD TREATMENT IMPROVES LONG TERM OUTCOME AND PATIENT QUALITY OF LIFE}

In 1998, Symmons et al examined the long term mortality outcome of a cohort of 489 patients with RA. ${ }^{21}$ The cohort was divided into three groups: early presenters (disease duration $\leqslant 5$ years); late presenters (disease duration $>5$ years); and the inception cohort with disease onset after 1 January 1964. With increased disease duration, the incidence of deaths due to infection, renal failure, and non-Hodgkin's lymphoma increased beyond that of the control population; patients with RA who presented and were treated early in the disease did better than late presenters. The study concluded that early treatment improves prognosis and that as a result the patients may have milder disease. ${ }^{21}$

Radiographic and clinical comparisons of patients with RA, treated or not treated with DMARDs, ${ }^{22}$ indicate that patients not treated with DMARDs had a significantly higher number of deformed and damaged joints. Clinical evidence indicated that long term use of DMARDs did not necessarily prevent radiographic progression of joint damage, but it significantly slowed the rate of progression compared with non-steroidal anti-inflammatory drug (NSAID) treatment alone. ${ }^{22}$

A large prospective follow up study of 2888 patients over 20 years assessed long term disability in patients treated with DMARDs. ${ }^{23}$ Increased DMARD use was associated with a bet- ter long term HAQ disability index, showing that consistent DMARD use resulted in a conservatively estimated 30\% reduction in disability over the duration of RA.

Each of the three trials represents category III evidence, supporting the statement that DMARD use improves the long term outcome and quality of life over the lifetime of patients with RA. ${ }^{24}$

\section{COMPARATIVE TOXICITY OF NSAIDS AND DMARDS}

DMARD treatment in the past was initiated when "NSAIDs no longer worked," and to a certain extent, this philosophy also served as a referral guideline when considering the aid of a rheumatologist in the treatment of patients with RA. This was based on the assumption that NSAIDs are a benign treatment for the early inflammatory stages of RA and that the potential toxicity of DMARDs precluded their use until the benefits outweighed the risks.

In recent years, it has been recognised that long term treatment with NSAIDs is associated with increased morbidity and mortality among patients with RA owing to the adverse effects of these drugs on the gastroduodenal mucosa. The more serious side effects of chronic NSAID use include peptic ulceration and upper gastrointestinal bleeding. Admissions to hospital and deaths in the American population related to gastrointestinal effects are estimated to be 26 000-47000 and 4400- 
Table 6 Delayed DMARD treatment trials in early RA

\begin{tabular}{|c|c|c|c|c|c|}
\hline $\begin{array}{l}\text { Author } \\
\text { (reference) }\end{array}$ & Study design & $\begin{array}{l}\text { Mean } \\
\text { disease } \\
\text { duration } \\
\text { (months) }\end{array}$ & Treatment & Outcome & $\begin{array}{l}\text { Evidence } \\
\text { category }\end{array}$ \\
\hline $\begin{array}{l}\text { Buckland-Wright } \\
\text { et } a P^{3}\end{array}$ & $\begin{array}{l}\text { Randomised, placebo controlled } \\
\text { trial; } 23 \text { patients, } 18 \text { month study }\end{array}$ & 8 & $\begin{array}{l}\text { Intramuscular gold } v 6 \text { or } 12 \\
\text { month delay of treatment }\end{array}$ & $\begin{array}{l}\text { Significantly reduced } x \text { ray } \\
\text { progression at } 6 \text { and } 12 \text { months }\end{array}$ & $\mathrm{lb}$ \\
\hline Egsmose et $a P^{4}$ & $\begin{array}{l}\text { Double blind, randomised, } \\
\text { placebo controlled trial; } 75 \\
\text { patients, } 60 \text { month study }\end{array}$ & 11 & $\begin{array}{l}\text { Oral gold } v \text { delayed treatment of } \\
8 \text { or } 12 \text { months }\end{array}$ & $\begin{array}{l}\text { Early treatment significantly reduced } \\
\text { swollen joint counts, } H A Q \text {, and } x \text { ray } \\
\text { progression }\end{array}$ & $\mathrm{lb}$ \\
\hline Munro et $a P^{5}$ & $\begin{array}{l}\text { Prospective trial of } 440 \text { patients; } \\
60 \text { month study }\end{array}$ & $\begin{array}{l}0-24 \\
24-60 \\
60+\end{array}$ & Intramuscular gold & $\begin{array}{l}\text { Significant reduction of } \mathrm{HAQ} \text { in the } \\
0-24 \text { month group }\end{array}$ & III \\
\hline Tsakonas et a $F^{6}$ & $\begin{array}{l}\text { Prospective trial of } 119 \text { patients; } \\
45 \text { month study }\end{array}$ & 9 & $\begin{array}{l}\text { Hydroxychloroquine } v \text { delayed } \\
\text { treatment of } 9 \text { months }\end{array}$ & $\begin{array}{l}\text { Early treatment group showed greater } \\
\text { improvement in pain index, functional } \\
\text { ability, and RA global wellbeing }\end{array}$ & III \\
\hline $\begin{array}{l}\text { van der Heide et } \\
\text { aP }\end{array}$ & $\begin{array}{l}\text { Open, randomised trial; } 238 \\
\text { patients, } 12 \text { month study }\end{array}$ & $<12$ & $\begin{array}{l}\text { IM gold, hydroxychloroquine or } \\
\text { methotrexate }\end{array}$ & $\begin{array}{l}\text { Early treatment group had significantly } \\
\text { reduced swollen and tender joints, } \\
\mathrm{HAQ}, \mathrm{ESR} \text {, and pain }\end{array}$ & lb \\
\hline
\end{tabular}

$H A Q$, Health Assessment Questionnaire; ESR, erythrocyte sedimentation rate.

Adapted from Quinn, Conaghan, and Emery. The therapeutic approach of early intervention for rheumatoid arthritis (submitted).

7700, respectively. ${ }^{25}$ Combined deaths related to chronic NSAID use in RA and osteoarthritis are estimated to be $\sim 16500$, which is comparable with the total number of deaths caused by the human immunodeficiency virus. ${ }^{25}$ Much of the clinical evidence for the toxicity of NSAIDs is derived from the Arthritis, Rheumatism, and Ageing Medical Information System (ARAMIS) database. ${ }^{26}$

Fries et al have compared toxicity profiles of NSAIDs and DMARDs by calculating a toxicity index derived from symptoms, abnormal laboratory measures, and admissions to hospital related to treatment. ${ }^{27}{ }^{28}$ Comparison of the quantitative toxicity estimates of NSAIDs and DMARDs indicates that there are no substantial differences between drug categories. ${ }^{27} 28$ Ibuprofen, naproxen, and sulindac each had toxicity indices comparable with that of intramuscular gold. $^{27} 28$

The long term toxicity of DMARD use is at least no worse than the toxicity of chronic NSAID use, a fact supported by category III and IV evidence. DMARD treatment is usually started within three years of diagnosis in $90 \%$ of patients with $\mathrm{RA}^{29}$; therefore, most patients with RA eventually are subjected to the risks of DMARD toxicity, and it is pointless to delay treatment that may improve both long term outcome and patient function if started early.

\section{CLINICAL EXPERIENCE: EACS}

Early arthritis clinics (EACs), located predominantly in Europe, have addressed the issue of early referral and treatment of patients with early RA, providing insight into the initial stages of RA. Table 4 summarises the risk factors identified by EACs, indicating potential baseline characteristics of patients with early RA likely to have persistent RA. A variety of selection criteria were employed in these EACs, including arthritis of $<12$ weeks, ${ }^{30}$ arthritis of $\geqslant 1$ joint for $\leqslant 6$ months, ${ }^{31}$ and arthritis of $<2$ years. ${ }^{32}$ In a clinical evaluation of 63 patients with mild, untreated, early arthritis seen at an EAC in the UK, Green et al found that the strongest predictor of persistent disease was a disease duration of $>12$ weeks. ${ }^{33}$

Kim and Weisman summarise the persistence of RA in the selected groups presenting at EACs compared with RA persistence in population based studies. ${ }^{18}$ Persistent RA, classified as compliance with either the 1958 American College of Rheumatology (ACR) or 1987 ACR diagnostic criteria or clinical diagnosis, was seen in $27-68 \%$ of the EAC patients. Population based investigations indicated that the prevalence of RA was decidedly smaller, of the order of 2.6-6\% in the groups studied. These observations indicate that the simple selection criteria employed in the EACs potentially allow the sensitive isolation of patients with RA whose disease is likely to be persistent and active.

The inherent problem with treatment of early RA is the long lag time between the onset of disease and referral to a rheumatologist for accurate and specific treatment. Specific analysis of the lag time between onset of symptoms and diagnosis of treatment, based on a review of medical records, ${ }^{34}$ indicates two factors that delay diagnosis: firstly, the time between symptom onset and the patient's subsequent visit to primary care providers and secondly, the length of time required to make the diagnosis. Because diagnosis of early RA is often difficult, the diagnostic lag time was found to be the major contributor to the overall delay in treatment. The median lag time to diagnosis in the study group was 18 weeks, with a shorter period for patients with progressive disease and seropositive for RF.

The rates of persistent disease reported in studies from EACs show the effectiveness of the early referral of patients to specialty arthritis clinics by primary care doctors and the selection and treatment of patients with progressive RA early in the disease. Van der Horst-Bruinsma et al compared patients with early RA $(n=233)$ referred to an EAC with patients ( $n$ $=241$ ) from a routine outpatient clinic. ${ }^{35}$ The study assessed the lag time between the onset of symptoms and referral to a rheumatologist, as well as the consistency of the initial diagnosis after one year. The referral criteria for the early RA group were defined simply as patients presenting with at least two of the following features: joint pain, joint swelling, or reduction of joint mobility with a duration of less than two years.

The conclusions of this investigation provide a nice summary of the early referral initiative. The study concluded that in $70 \%$ of cases the diagnosis of definite RA, as defined by the 1987 ACR classification criteria, can be made by a rheumatologist within two weeks after the first visit, including atypical cases. ${ }^{35}$ The diagnosis was reliable and was rarely changed over the one year study period. The observation that erosions are often noted at presentation "justifies considerable effort to motivate both patients and primary care doctors to regard early RA as a medical emergency and thereby to reduce the lag time even more." ${ }^{\prime 35}$

Recent evidence from an open, prospective, dynamic cohort study compared early DMARD treatment with delayed DMARD treatment for patients with recent onset RA $(<2$ years). ${ }^{36}$ The early treatment group had median disease duration of 130 days and the conventional treatment group 166 days. The conventional treatment group with an ACR diagnosis of probable or definite RA received NSAIDs at the point of inclusion in the study, and after $\sim 3$ months the patients with active disease received hydroxychloroquine or sulfasalazine. 
Rapid referral to a rheumatologist advised in the event of clinical suspicion of RA, which may be supported by the presence of any of the following (grade $C$ evidence):

$-\geq 3$ swollen joints 3946

- MTP/MCP involvement

- Squeeze test positive ${ }^{46}$

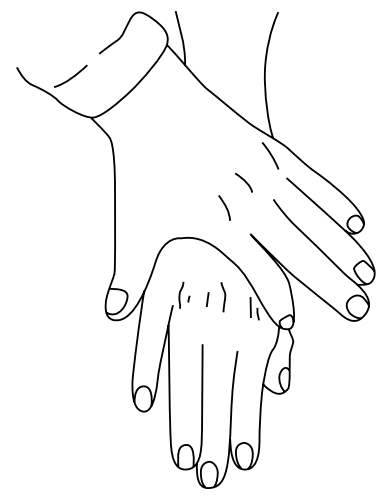

- Morning stiffness of $\geq 30$ minutes ${ }^{47}$ (Lard et al, submitted)
- Patients with RA have been shown to have an improved long term outcome, when treated by a rheumatologist (grade $\mathrm{C}$ evidence)

- There is evidence that a delay $>12$ weeks in treatment results in a missed opportunity to improve long term outcome (grade $\mathrm{C}$ evidence)

- RF positivity, raised acute phase response, and erosions on $x$ ray are associated with poor outcome. Their absence at presentation should not preclude diagnosis or referral (grade $\mathrm{C}$ evidence)

- NSAIDs can mask signs and symptoms at presentation (grade $D$ evidence)

- Corticosteroids should not be prescribed without an accurate diagnosis (grade D evidence)

Figure 1 Early referral algorithm for newly diagnosed RA.

Within two weeks of inclusion in the study, patients with definite and probable disease in the early treatment group were treated with either hydroxychloroquine or sulfasalazine, and the patients with less active RA were also treated with either hydroxychloroquine or sulfasalazine assigned at random.

Assessments included Health Assessment Questionnaire (HAQ) and radiographic joint damage, erythrocyte sedimentation rate (ESR) and CRP, morning stiffness, the number of swollen joints, and the Ritchie score. After only three months of treatment, the early treatment group showed significant reductions of ESR, CRP, and morning stiffness compared with the group receiving conventional treatment. ${ }^{36}$ Significant improvement in the duration of morning stiffness was sustained at one year with early treatment. Dramatic improvements were also shown by the Sharp score, which evaluates radiographic progression. After two years of treatment, the early treatment group had significantly less radiographic progression than the conventional treatment group, with no advancement of structural damage after the first year. Patient function, determined by the HAQ score showed clinically significant improvement at both one and two years. Conventional treatment showed a slight improvement in the HAQ score, which did not reach the clinically significant threshold.

The results of this study ${ }^{36}$ provide convincing evidence (III, C) of the crucial clinical benefit of early diagnosis and early DMARD treatment ( $>2$ weeks after inclusion in the study) compared with conventional treatment. Early intervention resulted in a favourable outcome over the two years of the investigation; however, long term follow up is needed to confirm the distinct advantage of early DMARD treatment.

\section{DURATION OF MORNING STIFFNESS}

Morning stiffness, a common problem of patients with RA, affects quality of life and ability to function in the morning. ${ }^{37}$ The duration of morning stiffness correlates with disease activity $^{113839}$ and is a component of the revised American Rheumatism Association (ARA) criteria for RA. ${ }^{40}$ However, morning stiffness as a quantitative evaluation of disease activity or as an outcome assessment in clinical trial may have limited validity. ${ }^{24}$ 41-44

Regardless of the quantitative power of its duration, morning stiffness is a commonly recognised clinical characteristic of RA. Indeed, morning stiffness and fatigue are often the first symptoms. ${ }^{45}$ The duration of stiffness specific for RA as defined by the revised ARA criteria ${ }^{40}$ is at least 60 minutes and present for six weeks, whereas morning stiffness associated with non-inflammatory joint diseases almost always lasts for less than 30 minutes. ${ }^{46}$ In accord with this observation, the duration of morning stiffness in early RA may be $\geqslant 30$ minutes (IV). An EAC study included a morning stiffness duration of $>30$ minutes as a predictor, among other indices, of active disease (Lard, unpublished data). ${ }^{36}$

\section{EARLY REFERRAL RECOMMENDATION FOR EARLY RA}

The graded clinical evidence provides clear support for the observations that: (a) permanent structural damage occurs early in the course of active $\mathrm{RA}^{24}{ }^{29}$ and $(b)$ early DMARD intervention slows the progression of structural joint damage $^{11}$ and improves long term outcome, as well as overall patient quality of life. ${ }^{24}$ These points establish the need for a reliable and sensitive method of referral, enabling the rapid diagnosis of active RA and the subsequent initiation of DMARD treatment.

Figure 1 shows the referral recommendation and represents an evidence based tool summarising essential diagnostic criteria derived from prospective clinical investigations of prognostic factors, EACs, and the consensus of the expert panel. Referral is recommended when there is clinical suspicion of RA, with emphasis placed on suspicion, as delay induced by the desire for a confirming diagnosis often results in disease progression before effective treatment is started. This is supported by the observation that serological markers of RA are often negative during the early stages of RA. ${ }^{18}$ The evidence category supporting the referral tool is predominantly category III, and therefore the recommendation is given a grade $\mathrm{C}$.

The composite compression test or "squeeze" test (fig 1), is a useful technique for clinical evaluation of a group of small, adjacent joints such as the metacarpophalangeal and metatarsophalangeal joints, and the use of this diagnostic test in the assessment of early RA has been recently validated. ${ }^{47}$ Tenderness in a single joint within the group can be isolated by gentle palpation of the individual joints. ${ }^{48}$ Summing the number of tender joints in this manner allows the clinician to determine the number of affected joints. The number of affected joints chosen for this referral recommendation is based on the revised ARA criteria ${ }^{40}$ and recent results from an 
EAC in the Netherlands, ${ }^{47}$ which specify swelling of three or more joints.

The qualifying points included in the referral recommendation lend additional support to the criteria. There is clinical evidence (III) indicating that patients with RA tend to maintain functional ability and quality of life over the long term when their RA is managed by a rheumatologist compared with a non-specialist. ${ }^{24}$ Recent clinical evidence (Lard unpublished data $)^{36}$ also shows that there may be only a brief opportunity during which early treatment may effectively stall the progression of RA. ${ }^{24}$

The compiled trials evaluating prognostic factors indicate that disease progression is likely when patients are RF positive and have raised levels of ESR and CRP ${ }^{24}$. However, because these factors are often negative in patients with active RA during the very early stages, their absence should not preclude referral

NSAID use often obscures RA progression, significantly masking symptoms ${ }^{49}$ by reducing inflammation (III, D). Corticosteroids can also mask RA progression, and owing to their potential adverse effects, should not be given without a confirmed diagnosis of RA (IV, D).

\section{CONCLUSION}

The evidence based recommendation for early referral of patients presenting with early RA represents a valuable tool for the practising clinician, enabling the identification of the rheumatoid patient with potentially active disease. By recognising the patients who are likely to have persistent disease and by starting DMARD treatment early, the debilitating effects of RA can be reduced, and long term outcome and patient quality of life can be improved.

\section{Authors' affiliations}

P Emery, Department of Rheumatology and Rehabilitation, University of Leeds School of Medicine, Leeds, UK

F C Breedveld, Department of Rheumatology, Leiden University Medical Centre, Leiden, The Netherlands

M Dougados, René Descartes University, Paris, France

J R Kalden, University of Erlangen-Nuremberg, Erlangen, Germany

M H Schiff, University of Colorado, Denver, CO, USA

J S Smolen, University of Vienna, Vienna, Austria

\section{REFERENCES}

1 Callahan LF. The burden of rheumatoid arthritis: facts and figures. $J$ Rheumatol 1998;25(suppl 53):8-12

2 Buckley CD. Science, medicine, and the future. Treatment of rheumatoid arthritis. BM 1997;315:236-8.

3 Criswell LA, Such CL, Yelin EH. Differences in the use of second-line agents and prednisone for treatment of rheumatoid arthritis by rheumatologists and non-rheumatologists. J Rheumatol 1997:24:2290.

4 Yelin EH, Such CL, Criswell LA, Epstein WV. Outcomes for persons with rheumatoid arthritis with a rheumatologist versus a non-rheumatologist as the main physician for this condition. Med Care 1998;36:513-22.

5 Ward MM, Leigh JP, Fries JF. Progression of functional disability in patients with rheumatoid arthritis. Associations with rheumatology subspecialty care. Arch Intern Med 1993;153:2229-37.

6 Solomon DH, Bates DW, Panush RS, Katz JN. Costs, outcomes, and patient satisfaction by provider type for patients with rheumatic and musculoskeletal conditions: a critical review of the literature and proposed methodologic standards. Ann Intern Med 1997;127:52-60.

7 Shekelle PG, Woolf SH, Eccles M, Grimshaw J. Clinical guidelines: developing guidelines. BM 1999;318:593-6.

8 van der Heijde DMFM. Radiographic imaging: the "gold standard" for assessment of disease progression in rheumatoid arthritis. Rheumatology (Oxford) 2000;39(suppl 1):9-16.

9 van der Heijde DMFM. Joint erosions and patients with early rheumatoid arthritis. Br J Rheumatol 1995;34(suppl 2):74-8.

10 Scott DL, Pugner K, Kaarela K, Doyle DV, Woolf A, Holmes J, et al. The links between joint damage and disability in rheumatoid arthritis. Rheumatology (Oxford) 2000;39:122-32.

11 Drossaers-Bakker KW, de Buck M, van Zeben D, Zwinderman AH, Breedveld FC, Hazes JM. Long-term course and outcome of functional capacity in rheumatoid arthritis: the effect of disease activity and radiologic damage over time. Arthritis Rheum 1999:42:1854-60.

12 Gough AKS, Lilley J, Eyre S, Holder RL, Emery P. Generalised bone loss in patients with early rheumatoid arthritis. Lancet 1994;344:23-7.
13 Devlin J, Lilley J, Gough A, Huissoon A, Holder R, Reece R, et al. Clinical associations of dual-energy $x$-ray absorptiometry measurement of hand bone mass in rheumatoid arthritis. Br J Rheumatol 1996;35:1256-62.

14 Deodhar AA, Brabyn J, Jones PW, Davis M, Woolf AD. Longitudinal study of hand bone densitometry in rheumatoid arthritis. Arthritis Rheum 1995:38:1204-10.

15 McGonagle D, Conaghan PG, O'Connor P, Gibbon W, Green M, Wakefield $R$, et al. The relationship between synovitis and bone changes in early untreated rheumatoid arthritis: a controlled magnetic resonance imaging study. Arthritis Rheum 1999:42:1706-11.

16 Backhaus M, Kamradt T, Sandrock D, Loreck D, Loreck D, Fritz J, et al. Arthritis of the finger joints: a comprehensive approach comparing conventional radiography, scintigraphy, ultrasound, and contrast-enhanced magnetic resonance imaging. Arthritis Rheum 1999;42:1232-45

17 Kraan MC, Versendaal H, Jonker M, Breshihan B, Post WJ, Hart BA, et al. Asymptomatic synovitis precedes clinically manifest arthritis. Arthritis Rheum 1998:41:1481-8.

$18 \mathrm{Kim}$ JM, Weisman MH. When does rheumatoid arthritis begin and why do we need to know? Arthritis Rheum 2000;43:473-84.

19 Anderson JJ, Wells G, Verhoeven AC, Felson DT. Factors predicting response to treatment in rheumatoid arthritis. The importance of disease duration. Arthritis Rheum 2000:43:22-9.

20 Kroot EJ, van Leeuwen MA, van Rijswijk MH, Prevoo MLL, Van't Hof $M A$, van de Putte LBA, et al. No increased mortality in patients with rheumatoid arthritis: up to 10 years of follow up from disease onset. Ann Rheum Dis 2000;59:954-8.

21 Symmons DPM, Jones MA, Scott DL, Prior P. Long-term mortality outcome in patients with rheumatoid arthritis: early presenters continue to do well. J Rheumatol 1998;25:1072-7.

22 Abu-Shakra M, Toker R, Flusser D, Flusser G, Friger M, Sukenik S, et al. Clinical and radiographic outcomes of rheumatoid arthritis patients not treated with disease-modifying drugs. Arthritis Rheum 1998;41:1190-5.

23 Fries JF, Williams CA, Morfeld D, Singh G, Sibley J. Reduction in long-term disability in patients with rheumatoid arthritis by disease-modifying antirheumatic drug-based treatment strategies. Arthritis Rheum 1996;39:616-22.

24 Edworthy SM. Morning stiffness: sharpening an old saw? [editorial]. J Rheumatol 1999:26:1015-17.

25 Wolfe MM, Lichtenstein DR, Singh G. Gastrointestinal toxicity of nonsteroidal anti-inflammatory drugs. N Engl J Med 1999;340:188899.

26 Singh G, Ramey DR. NSAID induced gastrointestinal complications: the ARAMIS perspective - 1997. J Rheumatol 1998;25:8-16.

27 Fries JF, Williams CA, Bloch DA. The relative toxicity of nonsteroidal anti-inflammatory drugs. Arthritis Rheum 1991;34:1353-60.

28 Fries JF, Williams CA, Ramey D, Bloch DA. The relative toxicity of disease-modifying antirheumatic drugs. Arthritis Rheum 1993;36:297-306

29 Emery P, Salmon M. Early rheumatoid arthritis: time to aim for remission? Ann Rheum Dis 1995:54:944-7.

30 Machold KP, Eberl G, Leeb BF, Nell V, Windisch B, Smolen JS. Early arthritis therapy: rationale and current approach. J Rheumatol 1998;25:13-19

31 Nissilä $M$, Isomaki H, Kaarela K, Kiviemi P, Martio J, Sarna S. Prognosis of inflammatory joint diseases. A three-year follow-up study. Scand J Rheumatol 1983;12:33-8.

32 Speyer I, Hazes JMW, Breedveld FC. Recruitment of patients with early heumatoid arthritis. The Netherlands experience. J Rheumato 1996;23:84-5

33 Green M, Marzo-Ortega H, McGonagle D, Wakefield R, Proudman S, Conaghan $\mathrm{P}$, et al. Persistence of mild, early inflammatory arthritis: the importance of disease duration, rheumatoid factor, and the shared epitope. Arthritis Rheum 1999:42:2184-8.

34 Chan KA, Felson DT, Yood RA, Walker AM. The lag time between onset of symptoms and diagnosis of rheumatoid arthritis. Arthritis Rheum 1994;37:814-20.

35 van der Horst-Bruinsma IE, Speyer I, Visser H, Breedveld FC, Hazes JMW. Diagnosis and course of early onset arthritis: results of a special early arthritis clinic compared to routine patient care. Br J Rheumatol 1998;37:1084-8

36 Lard LR, Visser H, Speyer I, van der Horst-Bruinsma IE, Zwinderman AH Breedveld FC, et al. Early vs delayed in recent onset rheumatoid arthritis patients: results from a two year controlled follow-up study in an early arthritis clinic [abstract]. Arthritis Rheum 2000;43(suppl):S154.

37 Wolfe F, Hawley DJ, Cathey MA. Clinical and health status measures over time: prognosis and outcome assessment in rheumatoid arthritis. J Rheumatol 1991;18:1290-7.

38 Möttönen TT. Prediction of erosiveness and rate of development of new erosions in early rheumatoid arthritis. Ann Rheum Dis 1988;47:648-53.

39 Jansen LM, van Schaardenburg D, van der Horst-Bruinsma IE, Bezemer $P D, D i j k m a n s$ BA. Predictors of functional status in patients with early rheumatoid arthritis. Ann Rheum Dis 2000;59:223-6

40 Arnett FC, Edworthy SM, Bloch DA, McShane DJ, Fries JF, Cooper NS, et al. The American Rheumatism Association 1987 revised criteria for the classification of rheumatoid arthritis. Arthritis Rheum 1988:31:315-24.

41 Felson DT, Anderson JJ, Boers M, Bombardier C, Chernoff M, Fried B, et al. The American College of Rheumatology preliminary core set of disease activity measures for rheumatoid arthritis clinical trials. Arthritis Rheum 1993;36:729-40.

42 van der Heide A, Jacobs JW, Dinant HJ, Biilsma JW. The impact of endpoint measures in rheumatoid arthritis clinical trials. Semin Arthritis Rheum 1992;21:287-94. 
43 Anderson JJ, Chernoff MC. Sensitivity to change of rheumatoid arthritis clinical trial outcome measures. J Rheumatol 1993;20:535-7.

44 Lineker S, Badley E, Charles C, Hart L, Streiner D. Defining morning stiffness in rheumatoid arthritis. J Rheumatol 1999;26:1052-7.

45 Harris ED Jr. Treatment of rheumatoid arthritis. In: Kelley WN, Harris ED Jr, Ruddy S, Sledge CB, eds. Textbook of rheumatology. Philadelphia: Saunders, 2000:933-50.

46 Moder KG, Hunder GG. Examination of the joints. In: Kelley WN, Harris ED Jr, Ruddy S, Sledge CB, eds. Textbook of rheumatology. Philadelphia: Saunders, 2000:353-70.

47 Visser H, Le Cessie S, Vos K, Breedveld FC, Hazes JMW. How to diagnose rheumatoid arthritis (RA) early: the development of diagnostic criteria [abstract]. Arthritis Rheum 2000;43(suppl 9):S154

48 Grahame R. Examination of the patient. In: Klippel JH, Dieppe PA, eds. Rheumatology. St Louis: Mosby, 2000:2.2.1-16

49 Marzo-Ortega H, Green M, Karim Z, Wakefield R, Quinn M, Emery P. Nonsteroidal anti-inflammatory drugs alter the presentation of early inflammatory arthritis. Rheumatology (Oxford) 2000;39(suppl 1):42

50 Brennan P, Harrison B, Barrett E, Chakravarty K, Scott D, Silman A, et al. A simple algorithm to predict the development of radiological erosions in patients with early rheumatoid arthritis: prospective cohort study. BM 1996;313:471-6.

51 Combe B, Dougados M, Goupille P, Cantagrel A, Meyer O, Eliaou JF, et al. Prognostic factors for radiographic damage in early rheumatoid arthritis (RA): a multiparameter, prospective study. Arthritis Rheum 2001;44:1736-43.

52 Feigenbaum SL, Masi AT, Kaplan SB. Prognosis in rheumatoid arthritis. A longitudinal study of newly diagnosed younger adult patients. Am J Med 1979;66:377-84

53 Gough A, Faint J, Salmon M, Hassell A, Wordsworth P, Pilling D, et al. Genetic typing of patients with inflammatory arthritis at presentation can be used to predict outcome. Arthritis Rheum 1994;37:1 166-70.

54 Möttönen T, Paimela L, Leirisalo-Repo M, Kautiainen H, llonen J, Hannonen P. Only high disease activity and positive rheumatoid factor indicate poor prognosis in patients with early rheumatoid arthritis treated with "sawtooth" strategy. Ann Rheum Dis 1998;57:533-9

55 van der Heide A, Remme CA, Hofman DM, Jacobs JWG, Bijlsma JWJ. Prediction of progression of radiologic damage in newly diagnosed rheumatoid arthritis. Arthritis Rheum 1995;38:1466-74.

56 van der Heijde DMFM, van Riel PLCM, van Leeuwen MA, Van't Hof $M A$, van Rijswijk MH, van de Putte LBA. Prognostic factors for radiographic damage and physical disability in early rheumatoid arthritis. A prospective follow-up study of 147 patients. Br J Rheumatol 1992:31:519-25.

57 van Leeuwen MA. Westra J, van Riel PLCM, Limburg PC, van Rijswijk $M H$. $\lg M, \lg A$, and $\lg G$ rheumatoid factors in early rheumatoid arthritis predictive of radiological progression? Scand J Rheumatol $1995 ; 24: 146-53$.

58 van Zeben D, Hazes JM, Zwinderman $A H$, Vandenbroucke JP Breedveld FC. Factors predicting outcome of rheumatoid arthritis: results of a follow-up study. J Rheumatol 1993;20:1288-96.

59 Eberhardt K, Fex E. Clinical course and remission rate in patients with early rheumatoid arthritis: relationship to outcome after 5 years. $\mathrm{Br} J$ Rheumatol 1998;37:1324-9.

60 Harrison BJ, Symmons DP, Brennan P, Bankhead CR, Barrett EM, Scott $D G$, et al. Inflammatory polyarthritis in the community is not a benign disease: predicting functional disability one year after presentation. J Rheumatol 1996;23:1326-31.
61 van Leeuwen MA van der Heijde DMFM van Rijswijk MH, Houtman PM, van Riel PLCM, van de Putte LBA, et al. Interrelationship of outcome measures and process variables in early rheumatoid arthritis. a comparison of radiologic damage, physical disability, joint counts, and acute phase reactants. J Rheumatol 1994:21:425-9.

62 Young A, Bielawska C, Corbett $M$, Roitt I. A prospective study of early onset rheumatoid arthritis over fifteen years: prognostic features and outcome. Clin Rheumatol 1987;6 (suppl 2):12-19.

63 Harrison BJ, Symmons DP, Brennan P, Barrett EM, Silman AJ. Natural remission in inflammatory polyarthritis: issues of definition and prediction. Br J Rheumatol 1996;35:1096-100.

64 Masi AT. Articular patterns in the early course of rheumatoid arthritis. Am J Med 1983;75:16-26.

65 Prevoo ML, van Gestel AM, van' t Hof MA, van Rijswijk MH, van de Putte LB, van Riel PL. Remission in a prospective study of patients with rheumatoid arthritis. American Rheumatism Association preliminary remission criteria in relation to the disease activity score. Br J Rheumatol 1996;35:1101-5

66 Tunn EJ, Bacon PA. Differentiating persistent from self-limiting symmetrical synovitis in an early arthritis clinic. Br J Rheumato 1993;32:97-103.

67 Wolfe F. The prognosis of rheumatoid arthritis: assessment of disease activity and disease severity in the clinic. Am J Med 1997;103/suppl $6 \mathrm{~A}): 12-18 \mathrm{~S}$

68 Australian Multicentre Clinical Trial Group. Sulfasalazine in early rheumatoid arthritis. J Rheumatol 1992;19:1672-7.

69 Borg G, Allander E, Lund B, Berg E, Brodin U, Pettersson H, et al. Auranofin improves outcome in early rheumatoid arthritis. Results from a 2-year, double blind, placebo controlled study. J Rheumatol 1988; 15:1747-54.

70 Davis MJ, Dawes PT, Fowler PD, Clarke S, Fisher J, Shadforth MF. Clinical practice: should disease-modifying agents be used in mild rheumatoid arthritis? $\mathrm{Br} J$ Rheumatol 1991;30:451-4.

71 Hannonen P, Möttönen T, Hakola M, Oka M. Sulfasalazine in early rheumatoid arthritis. Arthritis Rheum 1993:36:1501-9.

72 HERA Study Group. A randomized trial of hydrochloroquine in early rheumatoid arthritis: The HERA study. Am J Med 1995;98:156-68.

73 Buckland-Wright JC, Clarke GS, Chikanza IC, Grahame R. Quantitative microfocal radiography detects changes in erosion area in patients with early rheumatoid arthritis treated with myocrisine. J Rheumatol 1993;20:243-7.

74 Egsmose C, Lund B, Borg G, Pettersson H, Berg E, Brodin U, et al. Patients with rheumatoid arthritis benefit from early 2nd line therapy: 5 year follow-up of a prospective double blind placebo controlled study. J Rheumatol 1995:22:2208-13.

75 Munro R, Hampson R, McEntegart A, Thompson EA, Madhok R, Capell $H$. Improved functional outcome in patients with early rheumatoid arthritis treated with intramuscular gold: results of a five year prospective study Ann Rheum Dis 1998;57:88-93.

76 Tsakonas E, Fitzgerald AA, Fitzcharles MA, Cividino A, Thorne JC, $M^{\prime}$ Seffar $A$, et al. Consequences of delayed therapy with second-line agents in rheumatoid arthritis: a 3 year follow-up on the hydroxychloroquine in early rheumatoid arthritis (HERA) study. J Rheumatol 2000;27:623-9.

77 van der Heide A, Jacobs JWG, Biilsma JWJ, Heurkens AHM, van Booma-Frankfort $C$, van der Veen $M$, et al. The effectiveness of early treatment with "second-line" antirheumatic drugs: a randomized, controlled trial. Ann Intern Med 1996;124:699-707. 